\title{
AORTIC FLOW PROPAGATION VELOCITY AND ITS RELATION TO MAGNITUDE OF SHUNT IN PATIENTS WITH ISOLATED PATENT DUCTUS ARTERIOSUS
}

\author{
By
Ebrahim Mahmoud Zackzock**, Mohammad Ismail Al-Deftar, and Mansour M Mustafa \\ Department of Cardiology, Faculty of Medicine, Al-Azhar University, Cairo, Egypt \\ Corresponding author: Ebrahim Mahmoud Mohammed Zackzock
}

Mobile: 01093344264, E-mail: ebrahimzackzock2090@ gmail.com

\begin{abstract}
Background: Patent ductus arteriosus (PDA) is normally associated with hyperdynamic status. Given the presence of a vascular shunt between the aorta and pulmonary artery, intrinsic aortic changes occur (aortic stiffness). Arterial stiffness is currently regarded as an independent predictor of cardiovascular morbidity and mortality. There is a close relationship between arterial stiffness and aortic flow propagation velocity (AFPV).

Objective: To assess aortic stiffness in patients with isolated PDA using Doppler-derived AFPV, assess shunt magnitude i.e. pulmonary to systemic blood flow ratio (QP/QS) in patients with isolated PDA by echocardiography, compare AFPV values in patients with isolated PDA and apparently healthy individuals, and to correlate AFPV with PDA size and shunt magnitude.

Patients and Methods: Our study was performed at Bab EL-Sha'riya Hospital, Al-Azhar University during the period from September 2019 and August 2020, and consisted of twenty-five patients with isolated PDA, and twenty healthy controls. Detailed history, physical examination was performed and conventional twodimensional echocardiography was done to all cases then echocardiographic assessment of PDA including magnitude of the shunt by measuring QP/QS ratio. Aortic flow propagation velocity (AFPV) was measured in all cases.

Results: Patients with PDA exhibited significantly lower AFPV than the control ( $\mathrm{p}<0.001)$. AFPV was significantly correlated with systolic blood pressure $(r=-0.29 \& p=0.01)$. Also, there was significant correlation ( $r=-0.426)$ between AFPV and PDA size, mainly pulmonary end ( $\mathrm{p}=0.03)$, and magnitude of the shunt QP/QS ( $r=0.723 \& \mathrm{p}<0.001)$.

Conclusion: Transthoracic echocardiographic determination of the color M-mode propagation velocity of the descending aorta is a simple, non-invasive practical surrogate method in identifying arterial stiffness in patients with PDA and is related to effective orifice of PDA and magnitude of the shunt.
\end{abstract}

Keywords: Patent ductus arteriosus, aortic flow propagation velocity, magnitude of the shunt.

\section{INTRODUCTION}

The ductus arteriosus is a fetal blood vessel that closes soon after birth. In a PDA, the vessel does not close and remains "patent" (open), resulting in an irregular transmission of blood between the aorta and the pulmonary artery.

PDA is normally associated with hyperdynamic status. Given the presence of a vascular shunt between the aorta and 
pulmonary artery, intrinsic aortic changes occur (aortic stiffness). In addition, shunt injuries might be related to an inflammatory process, and endothelial dysfunction may increase the ageing of vessels, particularly the aorta, i.e. aortic stiffness (Jekell et al., 2013).

Quantification of shunt volume is the major goal of the hemodynamic evaluation of patients with PDA. However, there have been few reports of a straightforward and non-invasive echocardiographic method of quantifying flow across a PDA that correlates well with the cardiac catheterization findings (Galiè et al., 2016).

Arterial stiffness is currently regarded as an independent predictor of cardiovascular morbidity and mortality. There is a close relationship between arterial stiffness and target organ damage (Vasan et al., 2019).

Many studies have used aortic flow propagation velocity by M-Mode colourDoppler has as an indicator of aortic stiffness (Akdag et al., 2015).

The aim of this work was to assess aortic stiffness in patients with isolated PDA using Doppler-derived aortic flow propagation velocity, assess shunt magnitude (QP/QS ratio) in patients with isolated PDA by echocardiography, compare aortic flow propagation velocity values in patients with isolated PDA and apparently healthy individuals, and to correlate aortic flow propagation velocity with PDA size and shunt magnitude.

\section{PATIENTS AND METHODS}

This study involved patients with isolated PDA collected from the echocardiography lab of Bab EL-Sha'riya Hospital. The patients were screened for the study enrolment prospectively. The study was performed at Bab EL-She'riya Hospital, Al-Azhar University during the period from September 2019 and August 2020 .

The protocol and all corresponding documents were approved by Ethical and Research committee, Faculty of Medicine, Al-Azhar University and patients provided informed consents.

The participants were classified into two groups matched in sex and age:

Group (1): Patient group: 25 patients with isolated patent ductus arteriosus.

Group (2): Control group: 20 apparently healthy individuals.

\section{Inclusion criteria:}

Patients with echocardiographic diagnosis of PDA.

\section{Exclusion criteria:}

Patients with R-L shunt through PDA, documented ischemic heart disease, systemic hypertension, diabetes mellitus, moderate or severe valvular disease, ongoing arrhythmia or poor echocardiographic window.

\section{All subjects were exposed to:}

1. Full history taking, physical examination particularly arterial blood pressure, and resting 12-lead ECG.

2. Trans-thoracic 2D echocardiography and tissue doppler imaging: ECG gated complete 2D echocardiographic and doppler study was performed with the patient in the supine position using a Philips Affinity 50 ultrasound system 
(Philips Healthcare, Eindhoven, Netherlands) using S4 phased array probe $(1-5 \mathrm{MHz})$ and the following parameters were assessed: left atrium, aortic root, left ventricular dimensions, systolic and diastolic function (Lang and Roberto., 2015).

For diastolic function analysis, the mitral inflow signal was obtained from apical four chamber view, the $\mathrm{E}$ wave (early mitral inflow) and A wave (late mitral inflow) were measured, and E/A ratio was calculated. Mitral annular septal diastolic velocities in early diastole (E') and late diastole (A') were obtained by TDI and average E/E' was calculated.

Anatomic properties of the ductus were surveyed for extent, smallest thickness near the pulmonary end, shape, PDA orientation. PDA size was measured at the pulmonary end in the parasternal short axis and ductal views (Valente and King, 2012).

3. Echocardiographic assessment of shunt magnitude QP/QS (Baumgartner et al., 2010): The following parameters were assessed.

- Right ventricular outflow tract (RVOT) diameter from the PSAX view using the best optimized 2D image and zoom in close to the pulmonic valve during the greatest systolic expansion of the vessels.

- RVOT velocity time integral (VTI) was obtained by placing the pulsed wave doppler in the RVOT in the parasternal short axis (PSAX) view and tracing the signal 's envelope.
- Left ventricular outflow tract (LVOT) diameter from the parasternal long axis view using the best optimized 2D image and zoom in close to the aortic valve during the greatest systolic expansion of the vessels (mid systole) $0.5-1.0 \mathrm{~cm}$ of the AV orifice.

- LVOT VTI from the apical 5 chamber view by placing PW doppler as close as possible to the aortic valve in the centre of cross-sectional area CSA of LVOT then tracing the signal's envelope.

4. Estimation of aortic flow propagation velocity: Color M-mode Doppler measurements were obtained on the suprasternal view and recordings were obtained with the cursor parallel to the main flow of direction in the descending thoracic aorta. The color Doppler Nyquist limit was adapted to $30-50 \mathrm{~cm} / \mathrm{s}$, and switching to $\mathrm{M}$ mode with a recorder sweep rate of $200 \mathrm{~mm} / \mathrm{s}$, an M-mode spatio-temporal velocity map with the shape of a flame was displayed (Fig. $1)$. If the slope of the flame was unclear, the baseline shifting was used to change the aliasing velocity until a clear delineation of isovelocity slope was obtained. Tracing Aortic propagation velocity was measured by tracing the velocity slope of the first aliasing contour (Ghaderi, 2018).

\section{Statistical analysis:}

Data were tabulated and analysed using MedCalc (v.13) software. Continuous data were expressed as mean \pm standard deviation (SD), range. Categorial variables were expressed as frequency and percentage. 
The following tests were done:

- Mann-Whitney test was used to compare continuous variables of both groups.

- Chi ${ }^{2}$ test to test to compare categorial variables.

- Pearson correlation Coefficient (r) test was used for correlating data.

- Receiver operating characteristic (ROC curve) analysis was used to find out the overall predictivity of parameter in and to find out the best cut-off value with detection of sensitivity and specificity at this cutoff value.

- The confidence interval was set to 95\% and the margin of error accepted was set to $5 \%$. So, the p-value was considered significant at $\leq 0.05$.

\section{RESULTS}

- The study showed no statistically significant difference between patient and control group as regard demographic data or hemodynamic data, however the pulse pressure was higher in-patient group with statistically significant difference $(\mathrm{p}=$ 0.02) (Tables 1\&2).

Although the study included piediatric and adult cases with wide range of age ( 2 months -20 years), the majority of cases were under age of 5 years.

Table (1): Comparison between patients and control according to demographic data

\begin{tabular}{|c|c|c|c|}
\hline $\begin{array}{ll}\text { Groups } \\
\text { Demographic data }\end{array}$ & $\begin{array}{c}\text { Patient } \\
(\mathbf{n}=25)\end{array}$ & $\begin{array}{c}\text { Control } \\
(n=20)\end{array}$ & $\begin{array}{c}\text { p- } \\
\text { value }\end{array}$ \\
\hline \multicolumn{4}{|l|}{ Sex } \\
\hline Female & $19(76 \%)$ & $11(55 \%)$ & \multirow{2}{*}{0.24} \\
\hline Male & $6(24 \%)$ & $9(45 \%)$ & \\
\hline \multicolumn{4}{|l|}{ Age (months) } \\
\hline Mean \pm SD & $(75.44 \pm 70.83)$ & $(88.9 \pm 74.55)$ & \multirow{2}{*}{0.48} \\
\hline Range & $3-228$ & $2-264$ & \\
\hline Weight (kg) & & & \multirow{3}{*}{0.48} \\
\hline Mean \pm SD & $(23.83 \pm 17.15)$ & $(26.32 \pm 20.19)$ & \\
\hline Range & $7-60$ & $5-68$ & \\
\hline Hight $(\mathbf{c m})$ & & & \\
\hline Mean \pm SD & $(107 \pm 31.19)$ & $(110.55 \pm 29.50)$ & 0.59 \\
\hline Range & $60-160$ & $60-168$ & \\
\hline \multicolumn{4}{|l|}{ BMI } \\
\hline Mean \pm SD & $(18.6 \pm 4.54)$ & $(18.36 \pm 5.31)$ & \multirow{2}{*}{0.65} \\
\hline Range & $12.9-29.4$ & $13-30.6$ & \\
\hline \multicolumn{4}{|l|}{ BSA } \\
\hline Mean \pm SD & $(0.824 \pm 0.40)$ & $(0.874 \pm 0.44)$ & \multirow{2}{*}{0.53} \\
\hline Range & $0.37-1.63$ & $0.29-1.78$ & \\
\hline & & & \\
\hline
\end{tabular}

SD: standard deviation; BMI: body mass index; BSA: body surface area. 
Table (2): Comparison between patients and control according to hemodynamic data

\begin{tabular}{|c|c|c|c|}
\hline $\begin{array}{ll}\text { Hemodynamic data } & \text { Groups } \\
\end{array}$ & $\begin{array}{c}\text { Patient } \\
(\mathrm{n}=25)\end{array}$ & $\begin{array}{c}\text { Control } \\
(\mathbf{n}=20)\end{array}$ & $\begin{array}{c}\text { p- } \\
\text { value }\end{array}$ \\
\hline Systolic blood pressure & & & \\
\hline $\begin{array}{l}\text { Mean } \pm \text { SD } \\
\text { Range }\end{array}$ & $\begin{array}{c}(104.8 \pm 12.37) \\
(70-130)\end{array}$ & $\begin{array}{c}(100.75 \pm 11.03) \\
(80-120) \\
\end{array}$ & 0.26 \\
\hline $\begin{array}{l}\text { Diastolic blood pressure } \\
\text { Mean } \pm \text { SD } \\
\text { Range }\end{array}$ & $\begin{array}{l}(62.6 \pm 5.42) \\
(50-70)\end{array}$ & $\begin{array}{l}(64.25 \pm 8.31) \\
(50-80)\end{array}$ & 0.43 \\
\hline Heart rate & & & \multirow[b]{2}{*}{0.47} \\
\hline $\begin{array}{l}\text { Mean } \pm \text { SD } \\
\text { Range }\end{array}$ & $\frac{(96.28 \pm 22.75)}{(52-137)}$ & $\frac{(101.2 \pm 22.24)}{(71-146)}$ & \\
\hline $\begin{array}{l}\text { Pulse pressure } \\
\text { Mean } \pm S D \\
\text { Range }\end{array}$ & $\begin{array}{l}(42.6 \pm 9.58) \\
(25-60)\end{array}$ & $\begin{array}{c}(36.5 \pm 6.50) \\
(30-50)\end{array}$ & 0.02 \\
\hline
\end{tabular}

Patients with PDA exhibited significant increase $E$ velocity $(p=0.03)$, otherwise no statistically significant difference was found between both groups regarding other conventional and doppler echo parameters (Table 3).
Regarding

echocardiographic hemodynamic data patients had a statistically significant increase in in left ventricular stroke volume index LV SVI $(\mathrm{p}=0.006)$ and left pulmonary artery (LPA) VTI ( $\mathrm{p}=0.02)$ (Table 3).

Table (3): Comparison between patients and control according to different echo parameters

\begin{tabular}{|c|c|c|c|c|}
\hline \multicolumn{2}{|l|}{ Echocardiography } & $\begin{array}{c}\text { Patient } \\
(\mathrm{n}=25)\end{array}$ & $\begin{array}{c}\text { Control } \\
(n=20)\end{array}$ & $\begin{array}{c}\text { p- } \\
\text { value }\end{array}$ \\
\hline \multirow{2}{*}{ LADI (mm) } & Mean \pm SD & $36.5 \pm 12.2$ & $33.6 \pm 10.3$ & \multirow{2}{*}{0.50} \\
\hline & Range & $22.9-68.6$ & $17.4-58.8$ & \\
\hline \multirow{2}{*}{ LV EDD I(mm) } & Mean \pm SD & $52.49 \pm 14.6$ & $44.16 \pm 12.6$ & \multirow{2}{*}{0.12} \\
\hline & Range & $31.5-76.9$ & $24.3-69.2$ & \\
\hline \multirow{2}{*}{ E velocity } & Mean \pm SD & $109.12 \pm 18.9$ & $97.4 \pm 13.7$ & \multirow{2}{*}{0.03} \\
\hline & Range & $65-147$ & $82-124$ & \\
\hline \multirow{2}{*}{ LV SV I (ml) } & Mean \pm SD & $56.3 \pm 17.02$ & $43.96 \pm 18.5$ & \multirow{2}{*}{0.006} \\
\hline & Range & $33.6-90.8$ & $20.8-11.5$ & \\
\hline \multirow{2}{*}{ LPA VTI } & Mean \pm SD & $24.01 \pm 9.8$ & $18.21 \pm 2.5$ & \multirow{2}{*}{0.02} \\
\hline & Range & $11-45$ & $14.4-22$ & \\
\hline \multirow{2}{*}{ LV EF\% } & Mean \pm SD & $67.52 \pm 6.37$ & $64.6 \pm 5.44$ & \multirow{2}{*}{0.11} \\
\hline & Range & $54-77$ & $55-76$ & \\
\hline
\end{tabular}

LADI: left atrial diameter index; LV EDDI: left ventricular end diastolic dimension index; LV SV I: left ventricular stroke volume index; LPA VTI: left pulmonary artery velocity time integral; LVEF: left ventricle ejection fraction.

As regard characteristics of PDA and magnitude of the shunt in patients included in our study, there was a wide range of PDA sizes (Table 4). 
EBRAHIM MAHMOUD ZACKZOCK et al.,

Table (4): Characteristics of PDA in studied patients

\begin{tabular}{|c|c|c|c|c|c|c|}
\hline & P-PDA & A-PDA & L-PDA & $\begin{array}{c}\text { PDA- } \\
\text { SPG }\end{array}$ & $\begin{array}{c}\text { PDA- } \\
\text { DPG }\end{array}$ & QP/QS \\
\hline Mean \pm SD & $2.6 \pm 1.1$ & $7.38 \pm 4.2$ & $6.58 \pm 2.9$ & $78 \pm 26.1$ & $34.24 \pm 14.8$ & $0.78 \pm 0.10$ \\
\hline Range & $1.5-6$ & $2-15$ & $1.6-14$ & $33-124$ & $7-65$ & $0.6-0.9$ \\
\hline
\end{tabular}

P-PDA: Pulmonary end of PDA; A-PDA: aortic end of PDA; L-PDA: length of PDA; SPG: systolic pressure gradient; DPG: diastolic pressure gradient.

Our study demonstrated highly statistically significant difference between patient and control groups regarding
AFPV being lower in the patients (Table 5).

Table (5): Comparison between patients and control according to AFPV

\begin{tabular}{|c|c|c|c|}
\hline GFPV & $\begin{array}{c}\text { Patient } \\
(\mathbf{n = 2 5})\end{array}$ & $\begin{array}{c}\text { Control } \\
(\mathbf{n = 2 0})\end{array}$ & p-value \\
\hline Mean \pm SD & $33.14 \pm 7.7$ & $78.06 \pm 21.5$ & $<0.001$ \\
\hline Range & $18 \_47$ & $31 \_101$ & $<$ \\
\hline
\end{tabular}

The AFPV was negatively correlated with systolic blood pressure $(\mathrm{r}=-0.29 \& \mathrm{p}=$ $0.01)$ and pulse pressure $(r=-0.35 \& p=$ $0.001)$ in all cases, on the other hand no statistically significant correlation was found between AFPV and different echo conventional and Doppler parameters.

Analysis of AFPV among patients with PDA demonstrated that AFPV was negatively correlated size of PDA at its pulmonary end $(r=-0.426 \& p=0.03)$ but non-significant correlation with pressure gradient across PDA.

The most important finding in this study is that there was highly significant strongly positive correlation between AFPV and magnitude of the shunt QP/QS $(r=0.723 \& p<0.001)$ (Figure 1).

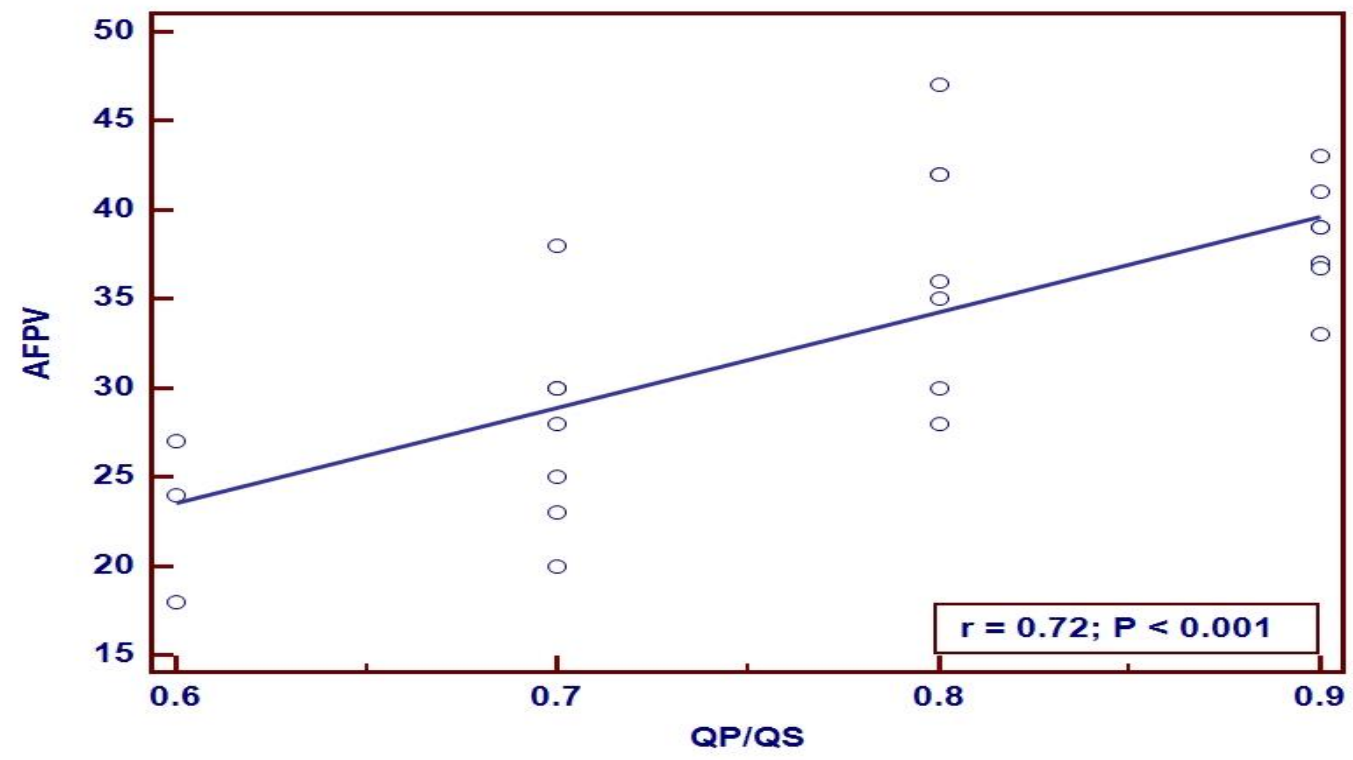

Figure (1): Correlation between AFPV and QP/QS 
Using receiver operating characteristic (ROC) curve, AFPV cut off value $>47$ had a sensitivity of $(85 \%)$ and a specificity of
$(100 \%)$ to exclude PDA shunt $(\mathrm{QP} / \mathrm{QS}<1)$ among patients with PDA (AUC :0.936, $\mathrm{P}$ value $>0.001$ ) (Figure 2).

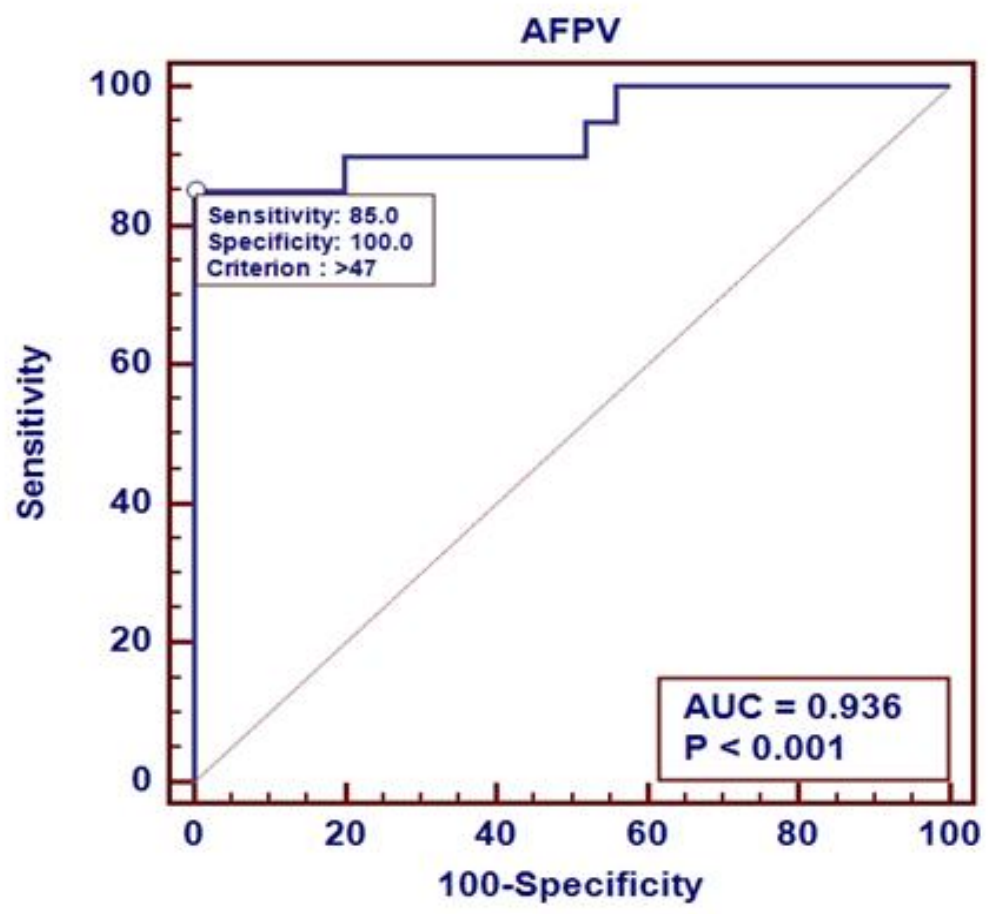

\section{Figure (2): $\quad$ ROC curve for AFPV in excluding PDA shunt}

\section{DISCUSSION}

PDA causes volume overload of the left side of the heart, which can lead to pulmonary hypertension. The planning of treatment for congenital heart deformities depends on the hemodynamic and anatomical circumstances when considering myocardial cell adjustment and chamber remodeling so it is critical to have various techniques for observing patients with PDA.

This study was the first study aimed to assess aortic stiffness in patients with isolated PDA using Doppler-derived aortic flow propagation velocity and correlate AFPV with both PDA size and shunt magnitude.
Our study included 25 patients with isolated PDA with different ages. However, most of them were less than 5 years and male to female ratio was 1:3 which was matching with the universal incidence of PDA (Perloff, 2012).

No statistically significant difference was found between patient and control group regarding demographic data, on the other hand the pulse pressure was significantly higher in patient group. This coincides with natural history of PDA and concordant with (Mahfouz, 2015).

The patient group exhibited significant difference in LVSVI being higher than the control group and significant increase in LPA VTI. This finding coincided with the hemodynamics of PDA, blood shunted 


\section{EBRAHIM MAHMOUD ZACKZOCK et al.,}

across PDA to pulmonary artery returns back to left atrium and increase LV preload and LVSV (Perloff, 2012).

The current study demonstrated wide range of PDA sizes from 1.5 to $6 \mathrm{~mm}$ at pulmonary end. This was comparable with another study (Elsaughier, 2019), which discovered the presence of aortic stiffness in patients with PDA using the aortic stiffness index as a marker of arterial stiffness.

AFPV have been used by many investigators for assessment of arterial stiffness and significantly decreased in many conditions associated with aortic stiffness as (Sahin, 2013, Akdag et al., 2015, Karaman, 2017, and Ghaderi, 2018).

Consequently, in the current study we used the AFPV as a marker of aortic stiffness for the first time in patients with PDA and revealed that it was significantly lower in patients with PDA than in control group. The explanation of this finding was that since the PDA was typically connected with the hyperdynamic status, and there was a vascular shunt between the aorta and pulmonary artery. Congenital aortic changes occur, i.e. aortic stiffness. Moreover, the shunt injuries may be related to a provocative inflammatory response and endothelial dysfunction may hasten the vascular aging (Jekell et al., 2013).

The present study, not only discovered the affection of AFPV by shunt injuries in PDA as a consequence of aortic stiffness, but also significant negative correlation between AFPV and effective orifice of PDA. This finding was in consistent with (Elsaughier, 2018). However, they used also aortic stiffness index as the marker of arterial stiffness.

The shunt magnitude can be assessed by different methods. In our study, we used the echocardiographic assessment of QP/QS. So, its results were less than 1. However, all included patients had left to right shunt as PDA was extra cardiac shunt. This study demonstrated a significant strong correlation between AFPV and QP/QS ratio. So, AFPV decreased in patients with PDA as a consequence of arterial stiffness and closely related to size of PDA and shunt magnitude.

Regarding the AFPV which is a novel echocardiographic method for assessment of aortic stiffness, our study documented statistically significant negative week correlation between AFPV and systolic blood pressure and pulse pressure. This finding was in concordance with (Gunes et al., 2012). However, they included only adult patients. On the other hand, this finding did not match with (Ari, 2017). This may be due to inclusion of only normotensive individuals in this study.

\section{STUDY LIMITATION}

1. Aortic stiffness was not evaluated using other aortic stiffness parameters, such as PWV or PWA and augmentation index.

2. Our study depended on echocardiographic method for determination of magnitude of the shunt QP/QS which was not the gold standard method as invasive assessment was beyond the scope of this study. 


\section{CONCLUSION}

Aortic flow propagation velocity as a parameter of aortic stiffness was fundamentally noted in patients with PDA, even those with small sized PDA and was related to effective orifice of PDA (pulmonary end) and magnitude of the shunt.

\section{REFERENCES}

1. Ari, H. (2017): Aortic propagation velocity does not correlate with classical aortic stiffness parameters in healthy individuals. Anatolian Journal of Cardiology, 340-346.

2. Akdag S, Akyol A, Cakmak H.A., Gunbatar H., Asker M., Babat N., Yaman M. and Gumrukcuoglu H.A. (2015): A novel echocardiographic method for assessing arterial stiffness in obstructive sleep apnea syndrome. Korean Circ J., 45(6):500-9.

3. Baumgartner, H. (2010): Canadian Cardiovascular Society 2009 Consensus Conference on the management of adults with congenital heart disease: Shunt lesions. Canadian Journal of Cardiology, 70-79.

4. Elsaughier, S.M. (2018): Aortic stiffness index and its association with cardiovascular functions in children before and after transcatheter closure of PDA.The Egyptian Heart Journal, 70: 261-266.

5. Elsaughier S.M., Ghaleb R. and Mansour H. (2019): Effect of time delay of PDA closure on the aortic stiffness index and its relationship with cardiac function. Cardiovascular Journal of Africa, 30:151-156.

6. Gunes A, Guntekin Ü, Yildiz S, Kaya BC, Deveci E and Kaya Z. (2012): Association of aortic flow propagation velocity with anklebrachial blood pressure index in patients with hypertension; an observational study. Anadolu Kardiyol Derg., 12: 568-73.

7. Galiè N, Hoeper MM and Humbert $M$. (2016): Guidelines for the diagnosis and treatment of pulmonary hypertension. Eur Heart J., 30(20):2493-2537.
8. Ghaderi, F. (2018): The predictive role of aortic propagation velocity for coronary artery disease. BMC Cardiovascular Disorders, 18 (121):1-7.

9. Jekell, A., Malmqvist, K., Wallén, N. H., Mörtsell, D. and Kahan, T. (2013): Markers of inflammation, endothelial activation, and arterial stiffness in hypertensive heart disease and the effects of treatment: results from the SILVHIA study. Journal of Cardiovascular Pharmacology, 62(6): 559-566.

10. Karaman, K. (2017): Aortic Flow Propagation Velocity in Patients with Familial Mediterranean Fever: An Observational Study. Korean Circulation Journal, 47(4):483489.

11. Lang A and Roberto $M$ (2015): Recommendations for cardiac chamber quantification by echocardiography in adults: an update from the American Society of Echocardiography and the European Association of Cardiovascular Imaging. Journal of the American Society of Echocardiography, 28(1): 1-39.

12. Mahfouz, R.A. (2015): Association of aortic stiffness to brain natriuretic peptide in children before and after device closure of patent ductus arteriosus. Journal of the Saudi Heart, 23-30.

13. Perloff JK (2012): Patent ductus arteriosus. In Clinical Recognition of Congenital Heart Disease. Pbl. Elsevier Saunders, pp: 368-393.

14. Sahin, M. (2013): A new echocardiographic parameter of arterial stiffness in end-stage renal disease. Herz, 39: 749-754.

15. Valenete AM and King ME (2012): Echocardiographic Evaluation of the Adult with Unoperated Congenital Heart Disease: Patent ductus arteriosus. In the Practice of Clinical Echocardiography Otto CM (ed), 4th Ed. Pbl. Elsevier Saunders, pp:865-866.

16. Vasan, R. S., Short, M.I. and Niiranen, T.J. (2019): Interrelations Between Arterial Stiffness, Target Organ Damage, and Cardiovascular Disease Outcomes. Journal of the American Heart Association, 8(14):1-14. 


\section{سرعة إنشار التدفق في الشريان الأبهر وعلاقتها بحجم التسريب فى مرضى القناة الشريانية المقتوحة}

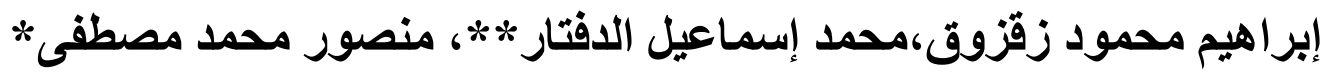

قسم القلب***، كلية الطب*، جامعة الأزهر بالقاهرة

E-mail: ebrahimzackzock2090@gmail.com

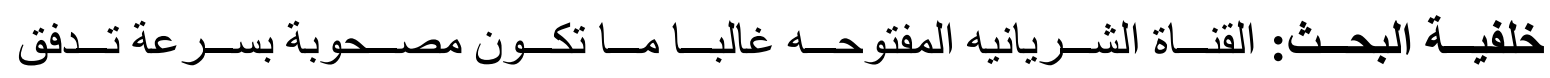

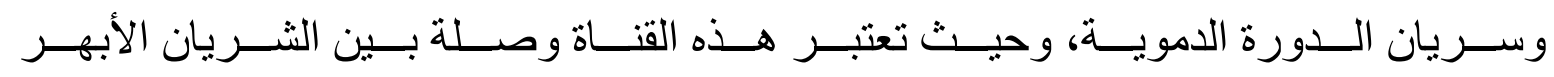

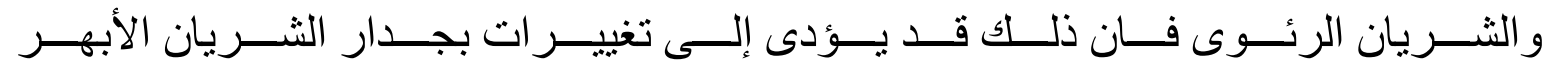

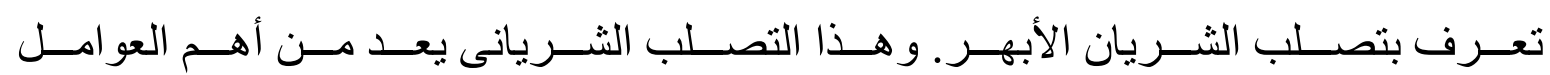

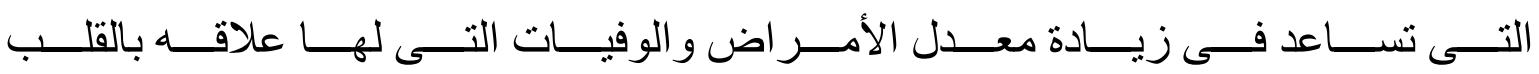

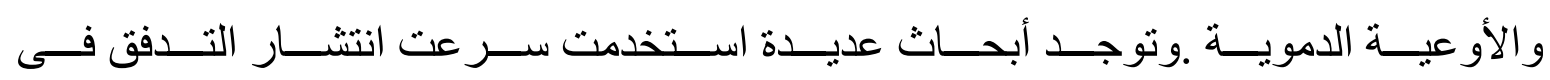
الثريان الأبهر كدلالة للتصلب الثريانى. وتودي

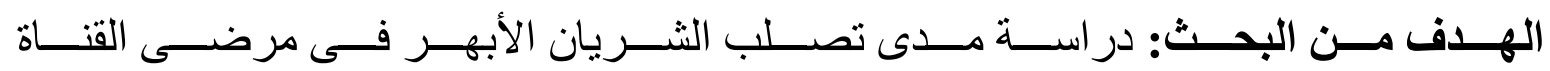

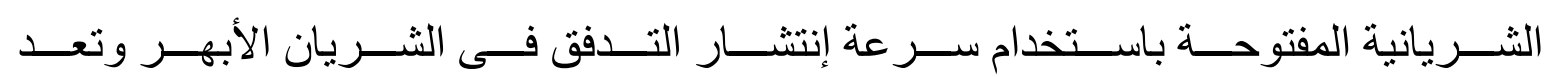

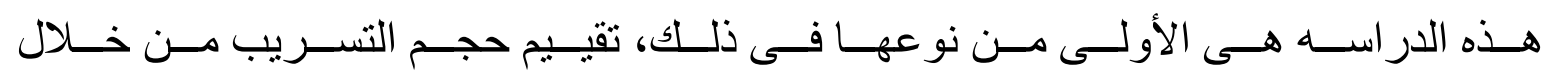

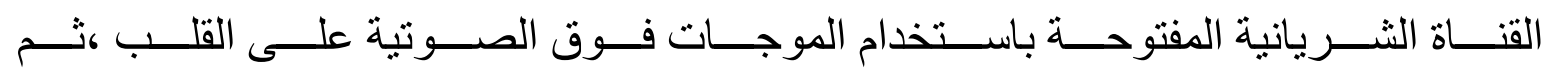

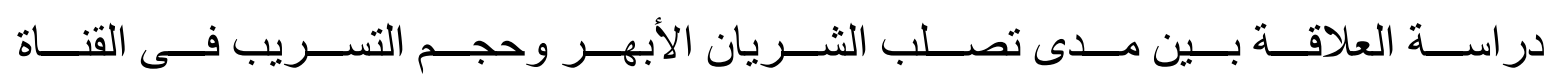
الثريانية المفتوحة.

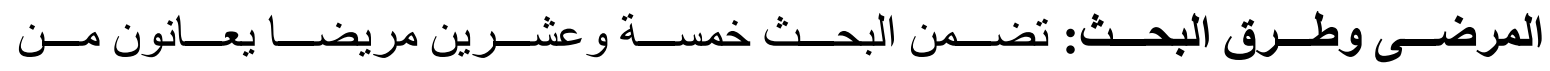

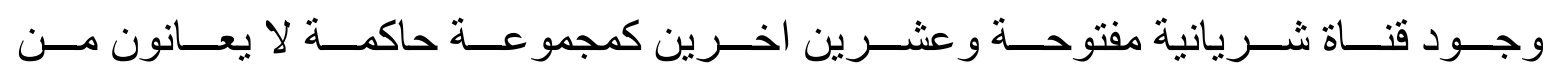

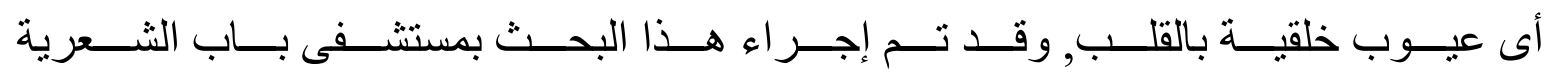

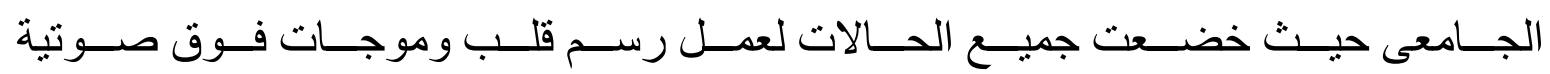
على القلب فى الفتره من سبتمبر 2019إلى أغسطس 2020. 
تتــائج البحـــث: كانـــت ســر عة انتشـــار التـدفق فـى الثـــريان الأبهــر فــى مرضــى

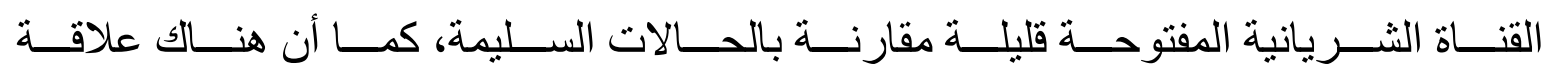
عكسـية بــين ســر عة إنتشـــار التــدفق فـى الثـــريان الأبهـــر وحجــم التشــريب فـى القناة الثريانية المفتوحة.

الإســـتـتاج: يمكــن اســتخدام در اســـة ســر عة إنتشـــار التــدفق فــى الثـــريان الأبهـــر

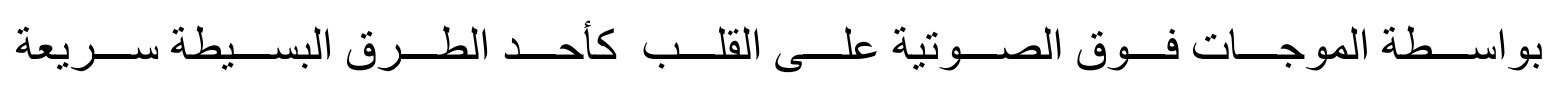

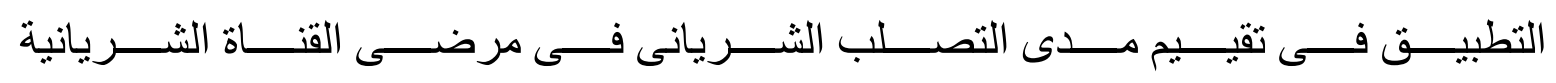
المفتوحة، كما أن لها علاقه بحجم القناة الثريانية وحجم التسريب بها. الكلمـــات الدالـــة: القتــاة الثـــريانية المفتوحــة، ســـر عة إنتشــــار التــدفق فـــى الثـــريان الأبهر ، حجم التسريب فى القناة الثريانية المفتوحة. 